\title{
The Collegie der Sçavanten: A Seventeenth-Century Cartesian Scholarly Society in Utrecht
}

\author{
Albert Gootjes
}

\begin{abstract}
Scholarship on Dutch academic culture of the Golden Age often evokes a 'college of savants' held to have been operative in Utrecht during the middle decades of that century, be it as a network of Cartesians or as a rather vague 'club' of sorts. In this article I weigh a variety of source materials, often highly polemically charged, to demonstrate that such a thing as the 'college' really did exist, and describe its members and activities from inception to demise. It emerges that a network of 'progressives' was established in the early 1650 s with the appointment of the Cartesians Johannes de Bruyn, Regnerus van Mansveld, Johannes Georgius Graevius, Francis Burman, and Louis Wolzogen to the university faculty, due at least in part to the secret scheming of the physician and councillor Lambertus van Velthuysen. This Cartesian network would clash repeatedly with the city's 'conservative' party, led by the influential theologian Gisbertus Voetius, often seeking freedom from the meddling and censure of the latter's Dutch Reformed church. I furthermore show how Van Velthuysen and company also began meeting weekly in the mid 166 os as a scholarly society, discussing a variety of literary, scientific, and philosophical themes in that closed setting until the early-to-mid 1670s. Above all, this scholarly society provided Utrecht's leading intellectuals with a platform where they could openly reflect on and think through the latest and most provocative ideas - including those of Spinoza - and their implications for religion, away from the alarmed cries of the Voetians and their prying interference.
\end{abstract}

\section{Introduction}

Throughout the social, political, and intellectual upheavals of the seventeenthcentury Dutch Republic, the city of Utrecht often found itself on center stage. Of course, towns such as Leiden, Amsterdam, and Groningen were hardly immune to the clashes between republicans (or 'Wittians') and Orangists, the campaigns for and against Cartesian philosophy, and the growing cleft dividing

(C) ALBERT GOOTJES, 2019 | DOI:10.1163/9789004389397_007

This is an open access chapter distributed under the terms of the prevailing CC-BY-NC License at the time of publication. 
the proponents of various currents of theological practice into 'Voetian' and 'Cocceian' camps. Nevertheless, in Utrecht these conflicts arguably reached a particular intensity due to the strength and vivacity of the former 'conservative' camp, under the leadership of Gisbertus Voetius (1589-1676), professor ordinarius of theology at the university as well as pastor to the city's Reformed church. Voetius, who today is associated above all with his intransigent defense of outdated standpoints, was in his own time a force to be reckoned with because of his influence on Dutch Reformed culture through pulpit and lectern, pen and press. ${ }^{1}$ His 'progressive' opponents were therefore forced to form a powerful front against him, which has led to the common evocation among scholars of a rather nebulous 'college of savants' (collegie der sçavanten).

The term collegie der sçavanten came into use after the publication of a nineteenth-century article by the Utrecht historian Jan Hartog, ${ }^{2}$ written after he had come across an anonymous 1674 pamphlet containing the name in its title. ${ }^{3}$ Imagining a fictional conversation between a pastoral candidate from Utrecht (Proponent) and a resident of the province of Holland (Hollander), this pamphlet reflects the new political situation following the end of the French occupation of Utrecht (1672-3), when the fortunes that had favored the city's republican elite for the better part of the previous two decades now shifted to their Voetian opponents, with far-reaching implications for the makeup of the vroedschap (city magistracy). ${ }^{4}$ The Proponent takes pains to warn his fellow traveler of a "Cartesian or Wittian college" in Utrecht, founded-after the example of the Catholic Council for the Propagation of the Faith and the Extirpation of Heresies - "for the extirpation of the truly pious and upright who love the church and the Prince, and for the propagation of Cartesian philosophy together with other related novelties." ${ }^{5}$ The pamphlet makes for entertaining reading, as the Voetian author not only identifies the main members of the 'college' but also launches a smear campaign against them to expose their errors, ranging from individual shortcomings like overfamiliarity with the wife

1 For an excellent treatment of Voetius, see the essay by Han van Ruler in The Dictionary of Seventeenth and Eighteenth-Century Dutch Philosophers, ed. Wiep van Bunge et al., 2 vols. (Bristol, 2003), 2:1030-9.

2 Jan Hartog, 'Het Collegie der Scavanten te Utrecht,' De gids 40 (1876), 77-114.

3 Het Collegie der Scavanten van Utrecht:Behelsende een samenspraeck tusschen een Hollander en Utrechts proponent (s.l., 1674, Knuttel cat. nr. 11240).

4 See D. J. Roorda, “The Utrecht “Government-Regulation”: Background, Events and Problems,' The Low Countries History Yearbook / Acta historiae neerlandicae 12 (1979), 85-109, there 99-106; and P. C. Wilders, Dienstbaarheid uit eigenbaat: regenten in het makelaarsstelsel van stadhouder Willem III tijdens het Utrechts regeringsregelement, 1674-1702 (Amsterdam, 2010), pp. $23-46$.

5 Het Collegie (see above, n. 3), p. A2r. 
of another 'savant' to the cabal-like mentality by which the members mutually protected one another from their respective positions. While Hartog indeed put the 'college of savants' on the map and continues to be cited as the author of the classic study about it, he in fact failed to make clear what the 'college' really might have been beyond a conniving group of Cartesian anti-Orangists, even if at one point he remarked that it must now be numbered among the growing number of 'societies' (genootschappen). ${ }^{6}$ More than that, Hartog was unable to offer much in the way of supporting evidence for the 'college,' having found just two additional, very brief references to it in pamphlets from the period. ${ }^{7}$ This doubtless explains why the name 'college of savants' has come to be used predominantly as a convenient collective term designating the members of Utrecht's Cartesian network, ${ }^{8}$ or else is described rather nondescriptly as a

6 Hartog, 'Het Collegie” (see above, n. 2), p. 102. Similarly, A. C. Duker, Gisbertus Voetius, 4 vols. (Leiden, 1897-1914), 3: 80 n. 1 ("dit gezelschap").

7 Hartog, 'Het Collegie' (see above, n. 2), p. 102. The pamphlets in question are Rehabeams raedt van Utrecht, behelsende de redenen der goede mannen van Utrecht, ende patriotten des Vaderlandts, waerom sy een request hebben over-gelevert aen sijn Excell: de Grave van Horne (s.l., s.a. [late 1673, or more probably early 1674], Knuttel cat. nr. 10974), p. 4; and, in response, Bileams raedt, ontdeckt en wederleydt, in het laster-boeckje, onlangs uyt-gegeven genaemt, Rehabeams raedt, tot Utrecht (s.l., 1674; Knuttel, cat. nr. 11189), p. 7. According to a contemporary rumor, Bileams raedt was authored by the Utrecht magistrate Johan van Mansveld. See Piet Steenbakkers, Jetze Touber, and Jeroen van de Ven, 'A Clandestine Notebook (1678-1679) on Spinoza, Beverland, Politics, the Bible and Sex,' Lias 38 no. 2 (2011), 225-365, there 300 (entry nr. 138): "Mansvelt senator composuit rehabiams raet [sic]." The text ought obviously to read "Bileams raet," since Rehabeams raedt was a pamphlet from the Voetian party, while Van Mansveld (for him, see below at n. 62) belonged to the opposing, republican faction.

8 See, for example, Caroline Louise Thijssen-Schoute, Het Nederlands Cartesianisme, ed. Theo Verbeek (Utrecht: 1989), p. 444, § 269: “Leiding is van Burman uitgegaan, hij verzamelde te Utrecht een kring van geestverwanten om zich heen, die bekend stond als het Collegie der scavanten." Similarly, M. J. A. de Vrijer, Henricus Regius: Een "cartesiaansch" hoogleeraar aan de Utrechtse Hoogeschool (The Hague, 1917), p. 62 ("het z.g. college der scavanten, d.w.z. ... een groep cartesiaansche geleerden"); Roorda, 'The Utrecht "Government-Regulation"' (see above, n. 4), 95 ("a circle"); J. C. Trimp, Jodocus van Lodensteyn: Predikant en dichter (Kampen, 1987), 140 ("een soort vriendenkring"); Wiep van Bunge, From Stevin to Spinoza: An Essay on Philosophy in the Seventeenth-Century Dutch Republic (Leiden, 2001), p. 100 ("a Utrecht circle of friends"); Alastair Hamilton, 'Arabists and Cartesians at Utrecht,' in: Leven na Descartes: Zeven opstellen over ideeëngeschiedenis in Nederland in de tweede helft van de zeventiende eeuw, ed. Paul Hoftijzer and Theo Verbeek (Hilversum, 2005), pp. 97-105, there 99 ("group of friends"); Jonathan I. Israel, Enlightenment Contested: Philosophy, Modernity, and the Emancipation of Man 1670-1752 (Oxford, 2006), p. 415 ("philosophical circle"), and Ester Bertrand, 'Johannes Swartenhengst (1644-1711): A Dutch Cartesian in the Heat of Battle' (Ph.D. diss., University of Edinburgh and Free University of Brussels, 2014), p. 33. 
"Cartesian club"9 or (less felicitously) a "gentleman's club."10 Not surprisingly, during the twentieth century some scholars began to doubt that such a 'college' had ever existed. ${ }^{11}$

Nevertheless, in a 1993 article on Dutch cultural societies predating at least some of these studies, Rienk Vermij briefly treated two letters of the 'savant' Johannes Georgius Graevius (1632-1703) confirming the reality of the collegie der sçavanten by his admission of membership in it—although, significantly, in doing so the Utrecht classicist countered the pamphlet's depiction of the 'college' as an anti-Voetian network of conspirators with his own description of an innocuous scholarly society, whose activities included the discussion of classical texts and scientific experimentation. ${ }^{12}$ In what follows I will build on Vermij's work, which unfortunately has received little scholarly attention, ${ }^{13}$ and will offer the first comprehensive account of the Utrecht 'college of

9 Theo Verbeek, Descartes and the Dutch: Early Reactions to Cartesian Philosophy 16371650 (Carbondale, Il., 1992), pp. 10, 75, 131. Similarly, Stephen Gaukroger, Descartes: An Intellectual Biography (Oxford, 1995), p. 473; and Roger Ariew et al., The A to Z of Descartes and Cartesian Philosophy (Lanham, Md., 2010), p. 44 s.v. "Burman, Frans."

10 Wiep van Bunge, 'Introduction,' in: Adriaan Koerbagh, A Light Shining in Dark Places, to Illuminate the Main Questions of Theology and Religion, trans. and ed. Michiel Wielema [Brill's Studies in Intellectual History 207] (Leiden, 2011), pp. 1-37, there p. 3.

11 H. J. de Vleeschauwer, 'Het alarm-pamphlet van Samuel Maresius bij het stadhouderschap van Willem III en de val van J. de Wit,' Tijdschrift voor Philosophie 2, no. 4 (1940), 551-86, there 571 n. 66: "Sindsdien [i.e., after Hartog] is wel twijfel opgerezen betreffende het bestaan van dit college. Het was wellicht niets meer dan een wekelijksch onder-onsje van gelijkdenkende vrienden." Similarly, Ferdinand Sassen, Studenten van de Illustre School te 's-Hertogenbosch 1636-1810 ter reconstructie van het album studiosorum [Mededelingen der Koninklijke Nederlandse Akademie van Wetenschappen, afd. Letterkunde 33 no. 2 (new series)] (Amsterdam, 1970), p. 12: “... 'Collegie der scavanten' ... waarvan het bestaan nog wordt betwijfeld."

12 Rienk Vermij, 'Genootschappen en de Verlichting: Enkele Overwegingen,' Documentatieblad werkgroep Achttiende Eeuw (1993), 3-23, there 15-7. The letters in question are J. G. Graevius to N. Heinsius (Utrecht, 29 and 30 April 1674), in: Sylloges epistolarum a viris illustribus scriptarum, 5 vols., ed. Pieter Burman (Leiden, 1727), 4: 256-8 (nr. 183) and 489-9o (nr. 416). The latter letter, erroneously dated 1677 by the editor Burman, is therefore separated from the former, with which it obviously belongs.

13 But see Eric Jorink, 'Comets in Context: Some Thoughts on Bayle's Pensées diverses,' in: Pierre Bayle (1647-1706), Le philosophe de Rotterdam: Philosophy, Religion and Reception, ed. Wiep van Bunge and Hans Bots [Brill's Studies in Intellectual History 167] (Leiden, 2008), pp. 51-67, there 61-2; idem, '“Outside God, There is Nothing': Swammerdam, Spinoza, and the Janus-Face of the Early Dutch Enlightenment,' in: The Early Enlightenment in the Dutch Republic, 1650-1750, ed. Wiep van Bunge [Brill's Studies in Intellectual History 120] (Leiden, 2003), pp. 81-107, there 65; and idem, Reading the Book of Nature in the Dutch Golden Age, 1575-1715, trans. Peter Mason [Brill's Studies in Intellectual History 191] (Leiden, 2010), pp. 156-7. Some details on the 'college,' developed independently of Vermij's work, can be found in Roberto Bordoli, Ragione e Scrittura tra Descartes e Spinoza (Milan, 1997), pp. 292-6. 
savants,' re-examining old data and bringing forth new evidence. Above all, I will demonstrate how the 'college' represented a platform where Utrecht's Cartesians could freely examine and debate the latest innovations in religion and philosophy during the mid-to-late seventeenth century, unhindered by the sorts of restrictions that would have been imposed within the public arena given the theological and political climate of the time.

There is no doubt that, as the Collegie der sçavanten pamphlet claims, by the third quarter of the seventeenth century a group of men were promoting Cartesian philosophy and republican, anti-Organist politics in Utrecht, particularly at the university. The presence of the 'Cartesian professors'14 on the faculty demonstrates how, in spite of the ban on Cartesian instruction that Voetius and his cohorts managed to have proclaimed in $1642,{ }^{15}$ the tides of power were constantly changing, such that the progressives were able to claim the odd victory. ${ }^{16} \mathrm{~A}$ first triumph came in 1652 , when the vroedschap appointed Johannes de Bruyn (1620-75), a professed Cartesian as evidenced in his 1644 pro gradu disputation on tides, professor of natural philosophy, a position he would hold for the next two decades. De Bruyn was the first Utrecht professor to openly offer Cartesian instruction. ${ }^{17} \mathrm{~A}$ second 'Cartesian professor' was added to the philosophical faculty in 1660 when Regnerus van Mansveld (1629-71), a wellconnected member of the city's patrician class, ${ }^{18}$ was appointed chair of logic and metaphysics. And the next year a third Cartesian, the aforementioned Graevius, was appointed professor of history and eloquence. Significantly, in a letter reporting on a trip to Utrecht made before assuming the post, Graevius hinted that the appointment had been made possible through secret efforts

\footnotetext{
14 This term is repeatedly used in Het Collegie (see above, n. 3).

15 See Verbeek, Descartes and the Dutch (see above, n. 9), p. 19.

16 As also argued by Tino Perlo, De Staten van Utrecht en Willem III:De houding van de Staten van Utrecht tegenover Willem III tijdens het eerste Stadhouderloze tijdperk (1650-1672) (Utrecht: 2000), pp. 46-7.

17 Sassen, Studenten (see above, n. 11), p. 23. On De Bruyn's Cartesianism, see also Rienk Vermij, The Calvinist Copernicans: The Reception of the New Astronomy in the Dutch Republic, 1575-1750 [History of Science and Scholarship in the Netherlands 1] (Amsterdam, 2002), pp. 169-72.

18 His father Antonius van Mansveld and his cousin Johan van Mansveld held various positions in the Utrecht government. See Roorda, 'The Utrecht "Government-Regulation"' (see above, n. 4), p. 95; and the manuscript on the Van Velthuysen and Van Mansveld families in Utrecht, Bijzondere Collecties van de Universiteitsbibliotheek Utrecht, Codices Belgici, cat. nr. 1828 , nr. 219 .
} 
undertaken by the Utrecht physician, philosopher, and theologian Lambertus van Velthuysen (1622-85). Writing to his mentor Johannes Fredericus Gronovius (1611-71), Graevius noted that Van Velthuysen's work on natural philosophy and morality represented full-fledged Cartesianism, then warned: "For that reason, we must take utmost care that it not be spread about that he and Wittich ${ }^{19}$ are behind this matter. For if that pontiff of this episcopal city ${ }^{20}$ and those who follow his sect were to find out, we will fail to obtain our wish."21

An Utrecht native of patrician stock, Van Velthuysen had studied theology at the orthodox Genevan academy from 1636 to 1639 before returning to his hometown to complete his studies. Back in Utrecht, he became a member of the French-speaking Walloon churches, ${ }^{22}$ where discipline was known to be less rigidly exercised than in the Dutch-speaking church from which he hailed. This move was a harbinger of things to come: Van Velthuysen was to break definitively with the orthodox camp by $1651-$ notwithstanding Voetius's high hopes for a career in the church ${ }^{23}$ — when he anonymously published a defense of Cartesian natural philosophy and an apology for Hobbes's De cive. ${ }^{24}$ Having added the title of doctor in both philosophy and medicine during the intervening years, Van Velthuysen abandoned his candidacy for the ministry and began to practice as a physician. And, as might be expected given his patrician status, he went on to accumulate a variety of appointments in church, government, and society at large, ranging from elder $\left(165^{-1}-3,1657-9\right.$, and

19 This is Christopher Wittich (1625-1687), at the time theologian at Nijmegen, who would go on to hold a chair at Leiden and become one of the leading voices within Dutch Cartesianism.

20 That is: the notorious (cf. ille) Voetius, to whom his adversaries commonly referred as the papa ultrajectinus. See Willem J. van Asselt, The Federal Theology of Johannes Cocceius (1603-1669), trans. Raymond A. Blacketer (Leiden, 2001), p. 86.

21 Letter of J. G. Graevius to J. F. Gronovius (Deventer, 24 December 166o), Munich, Universitätsbibliothek der Ludwig-Maximilians-Universität (hereafter: UB LMU), $2^{\circ}$ Cod., ms. 626, fol. 107v: "Multa enim prodi[erunt?] de causis rerum naturalium, nonnulla etiam de doctrina morum, sed totus est disciplinae Cartesianae. Idcirco diligentissime cavendum ne dispalescat illum \& Wittichium huius rei auctores esse. Nam si id resciverit summus ille pontifex urbis episcopalis, \& qui eius sectam sequuntur, votorum fallemur." Acts of the Utrecht Walloon consistory, Utrecht, Het Utrechts Archief (hereafter: HUA), Archief Waalse hervormde gemeente te Utrecht, inv. nr. 1, fol. 4or (22 December 1639).

23 Letter of G. Voetius to N. Blancardus (Utrecht, 21 November 1649), in: A. C. Duker, "Eenige onuitgegeven brieven van en aan Gisbertus Voetius," Archief voor Nederlansche kerkgeschiedenis 4 (1893), 276-325, there 304; and idem, Gisbertus Voetius, (see above, n. 6), $3: 266$.

24 Lambertus van Velthuysen, Disputatio de finito \& infinito, in qua defenditur sententia clarissimi Cartesii, de motu, spatio \& corpore (Amsterdam, 1651); and idem, Epistolica dissertatio de principiis justi et decori, continens apologiam pro tractatu clarissimi Hobbaei de Cive (Amsterdam, 1651). 
1669-71 ${ }^{25}$ to city physician $(1656)^{26}$ and governor to the Dutch West India Company (ca. 1663). ${ }^{27}$ Most importantly, in 1667 he became a member of the Utrecht vroedschap. ${ }^{28}$

Remarkably, Van Velthuysen never held a university post, in spite of his evident capacities. Yet from the beginning he remained close to the academic scene, such that a 1657 letter recommending a young man (Lamoraal van Nottelen) to study philosophy under De Bruyn was sent to Van Velthuysen rather than De Bruyn himself. ${ }^{29}$ Van Velthuysen's machinations to secure the appointment of Graevius in 1661 are therefore hardly surprising, and it is tempting to suppose that he was in some way responsible for the other Cartesian appointments from this period as well. In 1662 the Cocceio-Cartesian theologian Francis Burman (1628-79), at the time sub-regent to Leiden's Staten-college, was lured to the faculty of theology as Voetius's direct colleague - a particularly galling choice for the papa ultrajectinus and his followers, since Burman took the place vacated by their own Matthias Nethenus after his dismissal by the vroedschap. This was further aggravated by the pressure the vroedschap subsequently exercised on the consistory, in spite of its protestations, to add Burman as pastor and make him a member of the consistory. ${ }^{30}$ Then, in the spring of 1664, Louis Wolzogen (1633-90) was called to Utrecht as pastor to the Walloon church, and that fall was also appointed professor extraordinarius of church history ${ }^{31}$ While no evidence has surfaced yet to confirm Van Velthuysen's

25 For the three terms, see the acts of the Utrecht Walloon consistory in Utrecht (see above, n. 22), inv. nr. 1, fol. 85r (27 April 1651), and inv. nr. 2, fol. 1r (21 May 1671); as well as Livre synodal contenant les articles résolus dans les Synodes des Églises Wallonnes des Pays-Bas, 2 vols. (The Hague, 1896-1904), 1:561 (23-28 April 1659).

26 Acts of the Utrecht vroedschap, in: G. W. Kernkamp, Acta et decreta senatus: Vroedschapresolutiën en andere bescheiden betreffende de Utrechtsche academie, 3 vols. [Werken uitgegeven door het Historisch genootschap, 3rd series, vols. 65, 68, and 71] (Utrecht, 1936-1940), 1:317 (7 January 1656).

27 The earliest reference to this appointment can be found in the letter of J. G. Graevius to L. van Velthuysen (Düsseldorf, 3 August 1663), The Hague, Koninklijke bibliotheek (herafter: KB), collectie Koninklijke Nederlandse Akademie van Wetenschappen, KA 213 no. 9.

28 Duker, Gisbertus Voetius (see above, n. 6), 3:267.

29 Letter of C. Wittich to L. van Velthuysen (Nijmegen, 16 July 1657), Leiden, Universiteitsbibliotheek (hereafter: UB), Bibliotheca publica latina (hereafter: BPL), cat. nr. 750. This letter has also been published in Hans Bots, 'Témoignages sur l'ancienne université de Nimègue (1655-1671), Lias 19 no. 2 (1992), 215-53, there 230.

30 On Burman's appointment, see F. G. M. Broeyer, 'Franciscus Burman, een collega met verdachte denkbeelden,' in: Aart de Groot and Otto J. de Jong, eds., Vier eeuwen theologie in Utrecht (Zoetermeer, 2001), pp. 109-19, there 109-11.

31 P.J. H. Bodel-Bienfait, 'L'église wallonne d'Utrecht,' Bulletin de la commission pour l'histoire des églises wallonnes 3 (1888), 1-21, 241-92, and 4 (1890), 29-54, there 3: 19. 
involvement in securing the nominations of these other like-minded brethren, ${ }^{32}$ we still find, significantly, the Huguenot pastor Étienne le Moine (1624-89) thanking Van Velthuysen as late as 1671 for his efforts to obtain a position for him at the Walloon church and at the university in Wolzogen's place. ${ }^{33}$ So, too, would Theodore Craanen (1633-88) write him later that year to recommend a former student and fellow Cartesian, Benjamin van Broeckhuysen (1647-86), for the vacancy left by the unexpected passing of Van Mansveld, testifying once again to Van Velthuysen's perceived influence in faculty appointments. ${ }^{34}$

During the third quarter of the seventeenth century, the theologically orthodox, philosophically conservative, and politically Orangist party under the leadership of Voetius therefore came to face a growing number of progressive thinkers, with De Bruyn and Van Velthuysen as their senior members.

\section{$3 \quad$ Cohesion and Collusion}

The pamphlet Het Collegie der sçavanten identifies Van Velthuysen and the 'Cartesian professors,' along with the physician Henricus van Solingen, ${ }^{35}$ as the nucleus of the Utrecht 'college,' along with three student members named Johannes Fuyck, Specht, and Antonius van Schayk. ${ }^{36}$ Apart from the many

32 Wilhelm Goeters was the first to suggest that Van Velthuysen worked to have Wolzogen brought to Utrecht; see his Die vorbereitung des Pietismus in der Reformierten Kirche der Niederlände bis zur Labadistischen Krisis 1670 (Leipzig, 1911), pp. 135-6. However, there is no firm evidence confirming this supposition, not even - as Goeters's note appears to indicate-in the act by which the vroedschap approved the call. See Utrecht, HUA, Archief Stad Utrecht, secretarie 1577-1795, cat. nr. 121, nr. 27 (26 March 1664).

33 Letter of É. le Moine to L. van Velthuysen (Rouen, 7 March 1671), Leiden, UB, BPL, cat. nr. 885: "Je ne doute pas que Monsieur Grevius ne vous ayt déjà bien remercié de ma part, pour toute la bonté que vous avés fait paroître pour moy (ou qu'on a parlé de m'appeler en votre église, et en votre académie). Je vous en remercie encore de tout mon coeur...."

34 Letter of Th. Craanen to L. van Velthuysen (Leiden, 2 September 1671), Leiden, UB, BPL, cat. nr. 885 .

35 Pace Thijssen-Schoute, Nederlands Cartesianisme (see above, n. 8), p. 449, § 276, who erroneously identifies him as Nicolaas van Solingen. Nevertheless, Nicolaas, who served as schepen (alderman) and raad (councillor) in the Utrecht government, also appears to have been closely associated with the 'college'; see Collegie (see above, n. 3), p. A4r-v, and below, n. 70 .

36 Although the students' first names are not mentioned, Fuyck and Van Schayk are easily identified and appear as respondents to disputations that De Bruyn presided over; see below, n. 43. Two students named Specht appear in the Utrecht matriculation records of this time, but it is uncertain which of them was linked to the 'college'; see Album studiosorum Academiae Rheno-Traiectinae 1636-1886 (Utrecht, 1886), pp. 55 and $5_{6} 6$ (Hermannus, 1661 and 1662); and 58 (Philippus, 1664). 
defamatory accusations, a more serious complaint running throughout the pamphlet concerns the way these men collaborated as a cabal, and the surviving records suggest that the Voetians had a point. ${ }^{37}$ For starters, the men who gathered around De Bruyn and Van Velthuysen in the early 166os quickly formed a tight circle as they arrived in Utrecht. Thus in 1657 De Bruyn may have been the only person to whom the Amsterdam mathematician Johannes Hudde (1628-1704) asked Van Velthuysen to convey his greetings, ${ }^{38}$ but later 'college' correspondence tellingly includes frequent requests to pass on greetings to several 'savants. ${ }^{39}$ Baptismal records also indicate the cohesion among these men. In 1664 De Bruyn appeared as a godparent for Graevius's daughter Johanna Wilhelmina, and the following year Van Velthuysen and Burman's wife Maria Heidanus fulfilled this role for the young Aleida Graevius; in 1667 Wolzogen served as godfather to Nicolas Louys Graevius, who presumably was also named after him. ${ }^{40}$ These details would perhaps not be significant had not this social cohesion extended to mutual protection.

In 1654, when De Bruyn was still the only Cartesian professor on the Utrecht faculty and had gotten into hot water with the Dutch-speaking Reformed

37 This complaint is found among others also in Bericht, rakende de Cocceaensche en Cartesiaensche nieuwigheden in de theologie, waer in die eygentlijck bestaen en watse voor een quaedt gevolgh hebben. Uyt-gegeven ten eynde daer in mochte worden versien, tot conservatie van de ware gereformeerde religie, ende tot rust van de gemeynte (Amsterdam, 1674), pp. * $4{ }^{*} 5$. The complaint was also turned back on the Voetians, as can be seen in Voor-loper op het Beright raakkende de Coccejaansche en Cartesiaansche nieuwigheden in de theologie (Leiden, 1674), pp. 3-4, 7-8, 39, 43-44. I am indebted to Jo Spaans for drawing my attention to these pamphlets.

38 Letter of J. Hudde to L. van Velthuysen (Amsterdam, 13 October 1657), Amsterdam, University Library (hereafter UBA), отм D 29.

39 E.g., letter of J. G. Graevius to L. van Velthuysen (Düsseldorf, 3 August 1663) (see above, n. 27) (Burman, De Bruyn, Van Solingen); letter of J. Melchioris to J. G. Graevius (Ubiis [near Cologne], 23 July 1670), Copenhagen, Kongelige Bibliotek (hereafter: KB), Bibliotheca Thottiana, Ms Thott $12634^{\circ}$ (folder "Joh. Melchioris") (greetings for Burman and Van Solingen); letter of J. Perizonius to J. G. Graevius (Deventer, 5 January 1673), Leiden, UB, BPL 337, cat. nr. 106 (Van Velthuysen, Burman, De Bruyn); letter of J. Perizonius to J. G. Graevius (Deventer, 2 May [1673]), Leiden, UB, BPL 337, cat. nr. 105 (Van Velthuysen, Burman); and letter of J. Bouwmeester to J. G. Graevius (Amsterdam, 8 February 1676), Copenhagen, KB, Ms Thott $125^{8} 4^{\circ}$, nr. 19 (folder "Joh. Bouwmeester til J. G. Graevius") (Etiam Do. Solingio nostro salutem dicas aliisque amicis, et prae cateris Do. Velthusio).

40 Utrecht, HUA, Archief Burgerlijke stand van de gemeente Utrecht en van de voormalige gemeente Zuilen: retroacta doop- trouw- en begraafregisters, inv. nr. 5, p. 489 (27 February 1662); inv. nr. 20, p. 244 (5 July 1665), and p. 247 (3 December 1667). Presumably Nicolas Louys, who would die young, was named after Louis Wolzogen and Graevius's closest friend, the statesman Nicolaas Heinsius. After all, on 22 October 1673 Joachim Nicolaes Graevius was baptized and present as his godfathers were Nicolaas Heinsius and Joachim Nieuwstad; see ibid., inv. nr. 6, p. 413. 
church over student corollaries defended under his presiding, ${ }^{41}$ he, like Van Velthuysen and others seeking greater liberty, took refuge in the latitude offered by the Walloon church, which on that account had earned itself the derogatory name 'whiners' church' (pruylkerk). ${ }^{42}$ This may account for the provocative corollaries that seem to characterize De Bruyn's disputations a decade later, some defended by none other than two student members of the 'college,' namely Fuyck and Van Schayk. ${ }^{43}$ But it was certainly not the only factor. For by the mid-166os the Cartesian professors could feel relatively secure in their position at the university, enjoying protection from the vroedschap and having little to fear from the side of the consistory. A case in point concerns the events surrounding a 16 June 1666 disputation on the Holy Supper defended by Absalom Malecoot. This disputation included provocative corollaries from the defendant suggesting, among other things, that the Voetians' view on forgiveness under the old and new covenant dispensations risked being accused of Socinianism. The balance of power at the university may have left the conservatives handcuffed there, but when Malecoot soon thereafter requested an attestation from the Dutch Reformed consistory, it seized the opportunity to demand that he first account for his corollaries. Joined by Van Mansveld and Graevius, Burman —as the presiding professor-submitted a protest to the vroedschap, which took measures to protect the academic freedom of the university with a 26 January 1667 decision forbidding the consistory to formulate

41 Johannes de Bruyn, Disputatio mechanico-mathematica de trochlea ... (respondent: Theodore Craanen) (Utrecht, 1654), p. A4v (cor. 10): "Animae brutorum aeque sunt immortalitatis capaces ac hominum." See, on this affair, Vermij, Calvinist Copernicans, (see above, n. 17), pp. 279-80; and Duker, Gisbertus Voetius (see above, n. 6), 3: 82, n. 2.

Het Collegie (see above, n. 3), p. A3v. For the term, see François Halma, Woordenboek der Nederduitsche en Fransche taalen (Amsterdam, 1720), p. 642 s.v. "pruilen." The low opinion held by many Dutch Reformed of the standards in the Walloon church is reflected, for example, in Getrouwe en naader openeninge van het discours, voorgevallen tusschen den heer professor Johannes de Bruyn en Laurentius Homma ... (Utrecht, 1665), p. B4r. The earliest evidence for De Bruyn's presence in the Walloon church comes from spring 1663 , when his two-year term as elder came to an end; see the acts of the Utrecht Walloon consistory (see above, n. 22), cat. nr. 75, fol. 33v (17 May 1663).

43 E.g., Johannes de Bruyn, Disputationum philosophicarum de naturali Dei cognitione nona (respondent: Antonius van Schayk) (Utrecht, 1667), p. A4r: "3. Errores si velimus, evitate possumus.... 7. Motus terrae non contrariatur S. Script." Idem., Disputationum ... undecima (respondent: Johannes Fuyck) (Utrecht, 1667), p. A4v: "1. Philosophia et Theologia sunt duae scientiae, diversis principiis fundatae; illa igitur huic non potest dici esse subordinata. Attamen veritas philosophica nunquam pugnare potest cum veritate Theologica. [...] 9. Occultarum qualitatum nomina ignorantiae asyla esse. Affirm.... 12. Terram moveri. Aff.... 14. Cometae non sunt signa malorum." I thank Aza Goudriaan for making these disputations available to me; see also his Philosophische Gotteserkenntnis bei Suárez und Descartes, im Zusammenhang mit der niederländischen Theologie und Philosophie des 17. Jahrhunderts (Leiden, 1999), pp. 250 and 273. 
charges for ecclesiastical discipline on the basis of material derived from lectures, disputations, or corollaries. ${ }^{44}$ The following year, when the consistory censured the student 'savant' Fuyck for defending under Van Mansveld's presidence a corollary positing the necessity of Cartesian doubt, Graevius explicitly cited the former decision when he as rector once again approached the vroedschap to complain. ${ }^{45}$ Only months later did the Cartesian professors' position receive another boost when Van Velthuysen, recently inducted into the vroedschap, was appointed its 'political commissioner' "to see to it that nothing pertaining to and disturbing the commonwealth and politics was treated by the consistory." 46

Enjoying an increasing strength in numbers at the university over the first half of the 1660 s, the Cartesian professors' position came to be shored up also from the side of church and magistracy during the latter half of the decade. ${ }^{47}$ Under normal circumstances the consistory would have been the first channel through which the Voetians would have brought their grievances to the attention of the city government. Yet that route was made more difficult when Burman became a member of the consistory by virtue of his contested appointment as minister, and he doubtless used his position there to good effect in favor of the Cartesian circle to which he belonged. In fact, Burman'sperceived or real-betrayal of the consistory, perhaps most poignantly displayed in the Malecoot affair when he submitted charges against the very body of which he was a member, may well explain why he bears the brunt of the attacks in the pamphlet literature of the period. Furthermore, one can hardly underestimate the effect of Van Velthuysen's appointment as political commissioner, charged to attend the meetings of the consistory to ensure that it did not deal with anything beyond its province. In fact, his appointment itself illustrates the uncomfortable position of the Voetians during this time, since it was made in spite of his earlier clashes with the Dutch Reformed consistory

44 See Duker, Gisbertus Voetius (see above, n. 6), 3: 87-102. The Malecoot affair is raised in Rehabeams raedt (see above, n. 7), pp. 4-5; with a response in Bileams raedt (see above, n. 7), pp. 10-13.

45 See especially Duker, Gisbertus Voetius (see above, n. 6), 3: 82 n. 2, and the sources cited there. For the pamphlets, see Het Collegie (see above, n. 3), pp. A4v-Brr; Rehabeams raedt (see above, n. 7), pp. 5-6; and Bileams raedt (see above, n. 7), pp. 13-5.

46 Caspar Burman, Trajectum eruditum ... (Utrecht, 1750), pp. 385-6: "a magistratibus enim anno MDCLXVIII. ad conventus ecclesiasticos deputatus erat, ut videret, ne quid rem publicam vel politicam spectans ac perturbans a coetu ecclesiastico perageretur." The 'political commissioners' were introduced in 1660 amidst growing tensions between magistracy and consistory; see Duker, Gisbertus Voetius (see above. n. 6), 3: 161-70.

47 So also Perlo, Staten van Utrecht (see above, n. 16), pp. 46-7. This circumstance is also reflected in the acts printed in Kernkamp, Acta et decreta (see above, n. 26), 1: passim. 
over his writings questioning the extent of the church's authority. ${ }^{48}$ In fact, during his tenure Van Velthuysen would have been present at the very meetings of the consistory where it mobilized itself against his Tractaet van de afgoderye en superstitie (1669). ${ }^{49}$

There thus appears to be at least some truth to the Collegie der sçavanten pamphlet's description of the circle around De Bruyn and Van Velthuysen as a conniving network of Cartesian anti-Orangists.

\section{$4 \quad$ Scholarly Society}

This image, however, is challenged in two letters written in 1674 by the 'savant' Graevius to his closest friend, the statesman Nicolaas Heinsius the Elder $(1620-81) . .^{50}$ By that time Graevius and his friends no longer had the protection they had enjoyed in their heyday during the late 1660 s and early 1670 , and found themselves in a most vulnerable position. For following the end of the French occupation late in 1673 , Prince William III of Orange had disbanded the Utrecht vroedschap, and there was little doubt that the new composition would heavily favor the Voetians. ${ }^{51}$ Accordingly, Graevius lets on that he fears that he, Burman, and De Bruyn-i.e., all the remaining 'Cartesian professors,' following Wolzogen's departure for Amsterdam (1670) and Van Mansvelt's untimely death (1671) - will lose their positions at the university. He attributes this tight spot not only to his suspected Cartesianism, his friendship with the ousted magistrates, and his oration on comets but also to his participation in

the gathering of friends that for several years had the habit of meeting together every week to discuss various kinds of studies, in which

48 E.g., Het predick-Ambt en 't recht der kercke, bepaelt nae de regelen van Godts Woordt, en de gronden van onse Reformatie: tegen het gevoelen van eenige Gereormeerde Leeraers, die derselve macht verder uytbreyden als het behoort (Amsterdam, 1660). See the discussion in Willem Frijhoff and Marieke Spies, 1650: Hard-Won Unity, trans. Myra Heerspink Scholz (Assen, 2004), pp. 323-5.

49 Van Velthuysen's attendance as political commissioner is mentioned, for example, in the acts of the Utrecht Dutch Reformed consistory, in Utrecht, HUA, Archief Nederlandse hervormde gemeente Utrecht, kerkeraad, cat. nr. 9 (10 and 24 January, and 7 February 1670). For the controversy over the Tractaet, see Duker, Gisbertus Voetius (see above, n. 6), 3:267-90.

5o For these letters, see also Vermij, 'Genootschappen' (see above, n. 12), 15-7; and n. 12 above.

$5^{1} \quad$ See the literature cited in $n .4$ above. 
I expounded for these great magistrates ${ }^{52}$ some satires of Juvenal, and Suetonius, and Grotius's De iure belli et pacis. At times we also looked at the anatomy of the principal parts of the body, such as the heart, the eye, the ears, the spleen, and others, which work De Bruyn, a very good and most experienced master of dissection, performed for us. We also read new books as they were published, either about the causes of natural things or other matters, and debated about them. ${ }^{53}$

The account Graevius gives of the 'college of savants' thus differs radically from its depiction in the pamphlets. ${ }^{54} \mathrm{Far}$ from a band of conspirators, it was a 'scholarly society' that he and his likeminded friends had formed. The timing indicated by the Utrecht classicist furthermore leads one to assume it was initiated in the second half of the 166os, not long after the network of 'Cartesian professors' had been established, and continued until the early 1670s-long enough, at any rate, to still threaten Graevius's reputation when he wrote to Heinsius in the spring of 1674 .

While scholarly societies may be a phenomenon typically associated with the eighteenth century, ${ }^{55}$ there is no reason to doubt that the network that had gathered around De Bruyn and Van Velthuysen in the early 166os had formed a kind of society later that decade. ${ }^{56}$ These are, after all, the years of the establishment of the well-known Accademia del Cimento in Tuscany (1657), the Royal Society in London (1660), and the Académie royale des sciences in

$5^{2}$ praetextatis: literally 'those who wear the toga praetexta.' This was an outer garment worn by free-born children until they came of age, and by Rome's higher magistrates; see C. T. Lewis and C. Short, Latin Dictionary (Oxford, 1963), s.v. "praetexo," II.A.B.1. That Graevius envisions Utrecht's magistrate class is evident from the context, speaking in the preceding sentence of "those whose fortunes have recently been overturned" - that is, the ousted magistrates.

53 Letter of J. G. Graevius to N. Heinsius (Utrecht, 29 April 167[4]) (see above, n. 12).

54 Graevius explicitly identifies his description with what the pamphlets Het collegie and Rehabeams raedt called the 'college of savants'; see letter of J. G. Graevius to N. Heinsius (Utrecht, 29 April 167[4]) (see above, n. 12): "hoc Collegio doctorum: sic invidiose in probrosis, quibus exagitatur, libellis College de Scavants Gallico vocabulo appellant...."

55 See, for example, Wijnand W. Mijnhardt, Tot heil van 't menschdom: Culturele genootschappen in Nederland, 1750-1815 [Nieuwe Nederlandse bijdragen tot de geschiedenis der geneeskunde en der natuurwetenschappen 24] (Amsterdam, 1988), pp. 82-3. For some critical reflection, see Jan C. C. Rupp, 'Theatra anatomica: Culturele centra in het Nederland van de zeventiende eeuw,' in De productie, distributie en consumptie van cultuur, ed. J. J. Kloek and W. W. Mijnhardt (Amsterdam, 1989), pp. 13-36; and Vermij, 'Genootschappen' (see above, n. 12).

56 Graevius uses a variety of terms within the same semantic range: collegium, coetus, conventus, societas; see his letters to N. Heinsius (29 and 30 April 1674) (see above, n. 12). 
Paris (1667). And, closer to home, one might point also to the lesser-known Amsterdam Collegium privatum, founded in 1664, as an example for De Bruyn, Van Velthuysen, and their cohorts. ${ }^{57}$ Graevius's enormous correspondence network included leading members of almost all these societies, such as Lorenzo Magalotti (1637-1712) and Melchisédec Thévenot (1620-95), as well as Matthias Sladius (1628-89) and Niels Stensen (1638-86). While a directed search in potentially promising letters between these men and the Utrecht classicist has yielded no discussion of these other societies, it is difficult to imagine, given also the dynamics of the Republic of Letters, that they never spoke or wrote to one another about these matters. At any rate, for all the similarities between the 'college' and the better-known societies abroad, there is one important difference: while the other scholarly societies all left records of their proceedings, published works bearing their name, and the like, no such documents survive for the Utrecht 'college,' nor is there any indication that they ever existed.

This is not to say that nothing supports Graevius's description of the 'college' as a scholarly society, akin to the way the university and vroedschap records confirm at least part of the pamphlets' account regarding the collusion of its members. One specific aspect Graevius mentions in his letter to Heinsius is that the meetings were occasionally attended by the likes of the classicists Gronovius and Marquard Gudius (1635-89) or the naturalist Jan Swammerdam (1637-80), a member of the Amsterdam Collegium privatum. ${ }^{58}$ These men are obviously adduced as witnesses, with Graevius supposing that Heinsius's mind might now be triggered by something the late Gronovius had mentioned to him about a visit to the Utrecht 'college' in the course of their frequent correspondence. A search in their extant letters has yielded no definitive reference to the 'college' and its activities, however. ${ }^{59}$ Visitors' attendance, however, is indeed reflected in a letter to Graevius from another naturalist and close friend of Swammerdam, the Dane Niels Stensen, who in 1670 had to decline an invitation from Graevius to attend a meeting of the 'college.' Citing the serious illness of a housemate as his excuse, Stensen assures Graevius: "Were it not for [the illness], nothing would be more welcome to us than that most learned

57 See G. A. Lindeboom, 'Het Collegium privatum Amstelodamenses (1664-1673),' Nederlands tijdschrift voor geneeskunde 119, no. 32 (1975), 1248-54.

$5^{8}$ Letter of J. G. Graevius to N. Heinsius (Utrecht, 29 April 167[4]) (see above, n. 12).

59 But see perhaps the letter of J. G. Graevius to J. F. Gronovius (Utrecht, 3 March 1668), Munich, UB LMU, $2^{\circ}$ Cod., ms. 626, fol. 162r: "Iampridem te hic expectavimus.... Sed spero nos proximis feriis te hic visurum esse. Non ignoras quam desideratus non mihi solum meis quidem, sed \& nostris amicis omnibus sis venturus." 
companionship, where erudite men contend for victory with gentleness." 60 The setting Stensen depicts with this flowery accolade is a milieu where likeminded scholars can freely discuss and debate with a view to the advancement of science, recalling Graevius's insistence that the guests of the 'college' "extolled to the heavens the most pleasant and innocent enjoyment we derived from these discussions on various studies." ${ }^{\prime 1}$

The annotated title-page of Utrecht University's copy of the Collegie der sçavanten pamphlet provides another piece of evidence, since there an unidentified seventeenth-century person has listed the names of those whom he presumably considered to be the leading members of the 'college.' These include the names we have seen before-i.e., Wolzogen, Van Velthuysen, Graevius, Van Mansveld, Van Solingen, De Bruyn, and Burman-as well as Van Mansveld's cousin the Utrecht burgomaster Johan van Mansveld (1621-73) and the physician Everard van Sypesteyn $(1637-1716)$. On the face of it, one might be inclined to think that this information was simply taken from the text of the pamphlet. Nevertheless, the only mention of Johan van Mansveld occurs in a context other than membership, ${ }^{62}$ and Van Sypesteyn's name does not even appear in the pamphlet, suggesting that the annotator had access to inside information. And indeed, this impression finds confirmation in a final annotation added below the names, observing that Burman and De Bruyn "seldom came." 63 While this last annotation may fail to offer new information on the actual discussions held by the 'savants,' it does testify to the existence of the meetings and also suggests possible implications about the structure of the 'college.' After all, the pamphleteer explicitly sets Burman and De Bruyn apart from the other 'collegiants' (Collegianten) as, respectively, the chair (praeses)

6o Letter of N. Stensen to J. G. Graevius (Amsterdam, 20 April 1670), in: Nicolai Stenonis epistolae et epistolae ad eum datae, ed. Gustav Scherz (Freiburg, 1952), 1: 213: "Absque eo esset, nihil nobis optatius foret doctissimo illo contubernio, ubi cum humanitate eruditio [sic; read eruditi] de palma contendunt." I thank Eric Jorink for sharing his insights on this passage with me.

61 Letter of J. G. Graevius to N. Heinsius (Utrecht, 29 April 167[4]) (see above, n. 12): “... qui suavissimam hanc voluptatem \& innoxiam maxime, quam capiebamus ex his sermonibus de variis studiis, in coelum extollebant."

62 Het Collegie (see above, n. 3), p. A4r.

63 The complete annotations are as follows: "wolshogen velthuysen profesor greve [profesor] mansvelt mansvelt raatsheer Dr van solingen Dr sypesteyn profes de bruyn burman de twee laaste quamen selden." The annotated title-page of this copy held at Utrecht University has shelfmark: HS 3 L 17 dl 18. I am indebted to Jo Spaans and Piet Steenbakkers for help on this difficult transcription. 
and the vice (assessor). ${ }^{64}$ Indeed, Burman would have been the obvious choice for chair by virtue of his incomparable reputation, and the less flashy De Bruyn for vice chair on account of his seniority. Yet one wonders whether the pamphleteer gave the group a more formal organization than it actually had, so as to make it appear a larger threat— - just as he had coined the name 'college of savants' for this group, ${ }^{65}$ doubtless to give his Cartesian opponents an added air of pretentiousness. ${ }^{66}$

Further confirmation of Graevius's account of the 'college' is found in yet another annotated period pamphlet. During the French occupation of Utrecht, several citizens kept diaries in which they recorded details pertaining to military events, political decisions, outrages committed by the occupying party, and even the French officers' sociability. One such diary is Abraham de Wicquefort's Journael, of dagelijcksch verhael, published anonymously in 1674. The copy held at the Utrecht University Library is heavily interleaved with pages containing numerous remarks from a contemporary eyewitness keyed to specific passages of the Journael. ${ }^{67}$ At the place where De Wicquefort describes the controversial 1673 decision simply to extend the appointment of the incumbent Utrecht magistrates without the customary elections, ${ }^{68}$ the unidentified annotator added remarks totaling no less than eleven sides. He begins with the observation that in response to the pending continuation of the magistrates, "a number of mostly Wittian-minded conspirators held a

64 Het Collegie (see above, n. 3), p. A2v. This is doubtless the passage that suddenly transformed Burman into the very founder of the 'college,' as reported in Verbeek, Descartes and the Dutch (see above, n. 9), p. 75; Gaukroger, Descartes: An Intellectual Biography (see above, n. 9), p. 473; and Luisa Simonutti, 'Tra Cartesianesimo e Spinozismo: Limborch e la polemica con Burman,' in: Potentia Dei: L'onnipotenza nel pensioero dei secoli XVI e XVII, ed. Guido Canziani et al. (Florence, 2000), pp. 525-45, there 527 .

65 See the quotation from Graevius's letter to Heinsius in n. 54 above. At times the name has been understood to have come from the members themselves; see the discussion in $\mathrm{n} .82$ below.

66 For the pejorative use of 'sçavant' in the period, see, for example, the Voetian pamphlet Rehabeams regeering, ontdeckende d'intrigues der Machiavelsche politijken van Utrecht ... (Hamelen, 1674; Knuttel cat. nr. 1119o), pp. 8, 15 .

67 [Abraham de Wicquefort,] Journael, of dagelijcksch verhael van de handel der Franschen in de steden van Uytrecht en Woerden [...] (Amsterdam: Jan Claesz. ten Hoorn, 1674). The annotated copy is held at Utrecht University (shelfmark: Hs. 3.L.17), and has been included in the Annotated Books Online database coordinated by Arnoud Visser (Utrecht University). It can be viewed online at http://abo.annotatedbooksonline.com/\#binding-9-1 (accessed 5 April 2017).

68 [De Wicquefort,] Journael (see above, n. 67), p. 214. The same decision had been less controversial in the fall of 1672 , since it was imposed by command of the French and offered some stability so shortly after the invasion. 
meeting of that great savant college on 1 October," specifically naming "that great Argus ${ }^{69}$ Van Velthuysen, aside from that pompous and seasoned mind of Van Solingen ${ }^{70}$ who, having become a [city] councillor, beat his chest and said: 'I'll also make the [Provincial] States one day!"71 This brief remark of course calls into question Graevius's insistence that the 'college' was in no way politically motivated. Yet the annotator, who is significant for providing independent firsthand information, continues with a further description of the 'college' that does indeed confirm the overall tenure of the Utrecht classicist's characterization to Heinsius: "The 'college of savants' there was composed of ten men, almost all of them well-educated, who had the custom of meeting together at a certain place alone and set apart, since they always held heavy, deep, and erudite discussions there."72 This description of the discussions is easily matched with the list of 'college' activities detailed in the letter to Heinsius, just as this record of the October 1673 gathering in the wake of the continuation harmonizes well with Graevius's worries over his recent association with the 'college' in the spring of 1674 . What is new here, albeit hardly unexpected, is the annotator's indication - using a redundant expression (cf. alleen, afgesondert) — that the meetings of the 'college' were closed or restricted in nature.

The most significant source confirming Graevius's description of the 'college,' however, comes from the Groningen professor of theology Samuel Maresius (Desmarets, 1599-1673). ${ }^{73}$ In a brief 1672 Latin treatise soon translated into Dutch, the Huguenot theologian laments the deplorable state of theological instruction in the Dutch Republic at the time, targeting among other things

69 argus: presumably referencing Argos Panoptes, the many-eyed giant of Greek mythology, to depict Van Velthuysen as overly watchful.

$70 \quad$ I.e., Nicolaas van Solingen; see above, n. 35 .

71 [De Wicquefort,] Journael (see above, n. 67), fol. 87rº "1 october hebbe enige meest witte cabalisten vergaderinge gelegt van dat groote scavante collegie die groote argus velthuysen neffens dat hoogdravende wel door kneet verstant van solingen die geworden synde raat op syn borst klopte seggende hier steeckt nog een staten in." The men who opposed the decision were themselves incumbent magistrates, and as such stood to benefit from the proposed continuation. Their concern was thus procedural, perhaps anticipating the problems that they as republicans were bound to face after the imminent departure of the French occupiers. No doubt these republican men felt that if properly elected to their positions, the chance they would be ousted upon the arrival of the Prince of Orange-as indeed happened! - might be decreased.

72 [De Wicquefort,] Journael (see above, n. 67), fol. $87 \mathrm{r}^{\circ}$ : "NB het scavante collegie bestont aldaer uyt 10 persoonen meest alle wel door lettert die gewoon waren op seeker plaets alleen by een comst te hebben afgesondert alsoo aldaer altyt swaere diepsinnige en geleerde discoursen omgingen."

73 For Maresius, see the old but still excellent work from Doede Nauta, Samuel Maresius (Amsterdam, 1935). See also the entry in Theo Verbeek et al., The Correspondence of René Descartes: 1643 [Quaestiones infinitae 45] (Utrecht, 2003), pp. 279-82. 
the threat posed by Cartesianism. The city of Utrecht features prominently in his discourse, with Maresius pointing out how it had once led the attack on Descartes but has now become the "Acropolis and Capitol of Cartesianism."74 In a passage laced with classical allusions, Maresius continues:

For since several years ago, a number of Pinarian and Potitian ${ }^{75}$ brethren from the basest class of the Cartesian and Catalinarian ${ }^{76}$ religion had the habit of holding their weekly, drink-filled ${ }^{77}$ guild festivals, ${ }^{78}$ or rather assemblies $^{79}$ for the propagation of the Cartesian faith (Voetius used to call them the 'scholars' daily,' Le journal des savans $)^{80}$ in which they

74 Samuel Maresius, Tractatus brevis de afflicto statu studii theologici in Foederato Belgico (Groningen, 1672), p. 17. For the Dutch translation, which has the tendency to flatten the rather colorful language typical of Maresius throughout (so also De Vleeschauwer, 'Alarmpamflet" [see above, n. 11], 560), see Een kort en merck-weerdigh Tractaet, van den bedroefden toestant der H. Theologie in ons Vereenight Nederlandt ... (s.l., 1673), pp. B4v-Crr.

75 Pinarii \& Potitii: two of the most ancient patrician families of Rome, perhaps conveniently chosen by Maresius because of their association with eating and drinking; see An Universal, Historical, Geographical, Chronological and Poetical Dictionary, Exactly Describing the Situation, Extent, Customs ... of All Kingdoms ... (London, 1703), vol. 2, s.v. "Potitians and Pinarians": "The Potitians, as 't is said, had their name from $\pi \circ \tau i \zeta \varepsilon l v$, to Drink, because they only drunk the Liquors presented to the Gods; and besides they eat all the Victims, leaving none to the Pinarians, who had their Name from $\pi \varepsilon v \hat{\alpha} \alpha$, to Hunger." The Dutch simply translates as spits-broeders (brothers-in-arms).

76 Catilinariae: referencing the Roman senator Cataline (108-62 вСЕ), most probably for his hand in the Catilinarian conspiracy against the established consulship so as to reflect the Utrecht Cartesians' opposition to the Prince of Orange.

77 inter pocula (in the Dutch translation: onder den dranck): literally 'over drinks,' but doubtless used insinuatingly here. Cf. how the Reformed theologian Marcus Friedrich Wendelin in his ethical manual discusses the question whether deliberations ought to be made over drinks (An inter pocula sit deliberandum?), concluding that the more prudent will respond negatively; Philosophia moralis, praeceptis succinctis methodice comprehensa, 2nd rev. ed. (Harderwijk, 1654), pp. 897-9 (1.1.35, §§ 45-8).

78 suas Mercuriales: in Roman religion, Mercury was the god of commerce, whom the merchants' guild honored on the Ides of May. Thus the Dutch translation: gilde-dagh (literally 'guild day').

79 Congregationes: Maresius plays here on the Roman Catholic Congregation for the Propagation of the Catholic Faith, by this time a notorious agent of persecution against Protestants. The same comparison between the Utrecht Collegie and the Catholic 'Congregation' can be found in Het Collegie (see above, n. 3), p. A2r.

8o Eruditorum diarium, le journal des savans: according to Maresius's report, Voetius compared the meetings to dailies, presumably for informing their attendees/readers of the latest scientific news. In Dutch the passage is translated: "welke vergaderingen D. Voetius pleeght te noemen het dagh register der geleerde, lejournal [sic] des savants." It is not clear whether Voetius and Maresius were explicitly referencing the famous Journal des savans $\left(1665^{-}\right)$of the French Académie royale here. For misinterpretations of this passage, see n. 82 below. 
contrived careful plans for promoting their sect in both theory and practice. The gathering was chaired by Van Velthuysen, a man hardly troubled by Godhead or piety; it was also attended by the theologian Burman, and several other sworn-in professors of philosophy and the arts. ${ }^{81}$

This is a difficult passage on several accounts, so one should not be surprised to find that its importance for the 'college' has been overlooked or underestimated. ${ }^{82}$ Nevertheless, when the classical references are properly placed and the overt vilification typical of the ever-belligerent Maresius is stripped away, his description of the Utrecht Cartesians, presumably gained from his former nemesis Voetius with whom he had finally allied himself in 1668, is entirely in line with the other known sources. With De Bruyn, Van Mansveld, and Graevius easily recognizable as the "professors of philosophy and the arts," Maresius's list of participants closely matches the principal Collegianten identified in the Collegie pamphlet. Moreover, like Graevius, the well-informed Maresius clearly describes weekly meetings devoted to scholarly pursuits, and so too the informal setting he depicts - albeit with highly insinuating terms - matches well with the Utrecht classicist's depiction of gatherings held among friends. While some discrepancy with the pamphlet remains by virtue of the Huguenot theologian's identification of Van Velthuysen (rather

81 Maresius, Tractatus brevis (see above, n. 74), p. 17: "Solebant enim ab aliquot annis nonnulli Pinarii \& Potitii fratres ex ima cavea Religionis Cartesianae \& Catilinariae, singulis septimanis suas Mercuriales habere inter pocula, sive potius suas Congregationes de propaganda Cartesiana fide, quarum quamque D. Voetius solebat, Eruditorum diarium, le journal des savans, appellare, in quibus de secta sua promovenda, tam Theorritice quam Practice subtilia agitabant consilia; Praeses conventus erat Velthusius, homo Numinis \& Pietatis sic satis securus; Aderat Burman. Theologus, \& quidam alii intimae admissionis Professores Philosophiae \& artium...."

82 In paraphrasing the passage from Maresius's Tractatus brevis above, the Dutch church historian Christiaan Sepp misunderstood the text on multiple points and erroneously reported that Maresius was expressing his displeasure at the way Van Velthuysen and Burman had treated his Systema in the Journal des savans; see his Het godgeleerd onderwijs in Nederland, gedurende de $16^{e}$ en $17^{e}$ eeuw, 2 vols. (Leiden, 1873-4), 2: 488. Hartog read Sepp but clearly failed to consult the Tractatus brevis itself, so that this crucial evidence regarding the 'college' escaped his notice. Rather, he erroneously posited on the basis of Sepp that the Collegie der sçavanten may owe its name to the members' contribution to the Journal des savans. See Hartog, 'Collegie' (see above, n. 2), p. 103; so too ThijssenSchoute, Nederlands Cartesianisme (see above, n. 8), p. 444, § 269. Most remarkably, De Vleeschauwer did see the connection to the Collegie in Maresius's pamphlet, butperhaps out of ignorance of the Graevius letters-dismissed it as never having had a formal existence; see above, $n$. 11. This passage is also cited, albeit with scant commentary, in Bordoli, Ragione e Scrittura, (see above, n. 13), p. 292, who does connect it to the Collegie pamphlet, but he was apparently unaware of the Graevius letters. 
than Burman) as the society's chair, the timeframe shows Maresius once again to be not far from what Graevius himself would later write.

\section{$5 \quad$ Drafts and Pamphlets}

Maresius also reveals additional details he had gained about the meetings of the Utrecht Cartesians, doubtless through his considerable network. He thus notes that "the intimacy between the sworn members was so great that they shared their latest drafts [suos novos conceptus] with each other, and sent them to others"83 — that is, to other leading Cartesians in the Dutch Republic (and beyond), whom he colorfully describes as "birds of the same feather [aves concolores] in Leiden, Amsterdam, Nijmegen, Duisburg, Franeker, and perhaps Groningen." ${ }^{4}$ Maresius himself is interested particularly in the external correspondence of the 'college', since it forms the basis for the defamatory observation that entire sentences in the judgments on his Systema issued by Utrecht's Burman and Nijmegen's Wittich show such marked verbal similarities that the one must have taken them over from the other (in a pre-publication draft version).$^{85}$ For our purposes, however, it is also worthwhile dwelling on the exchange of ideas, which presumably took place during the sessions the 'savants' held together. For at the end of this passage Maresius cynically speaks of "the Trophonian cave ${ }^{86}$ of the Utrecht Dinner Sophists, ${ }^{87}$ where each of them presented his contribution." 88 Such exchange of ideas was not something Graevius had mentioned in his account of the 'college' to Heinsius, but it is of course entirely in line with the other activities he had outlined.

83 Maresius, Tractatus brevis (see above, n. 74), p. 17.

84 See, similarly, Het Collegie (see above, n. 3), p. B2r, which identifies the following men to be the correspondents of the 'college': Abraham Heidanus in Leiden, Antonius Perizonius in Deventer, Wittich in Nijmegen, and Balthasar Bekker in Franeker.

85 That is: Samuel Maresius, Collegium theologicum, sive Systema breve universae theologiae ..., first published in 1645, but with numerous subsequent, revised editions; Franciscus Burman, Synopsis theologiae et speciatim oeconomiae Foederum Dei ... (Utrecht, 1671); and Christopher Wittich, Theologia pacifica, in qua varia problemata theologica inter reformatos theologos agitari solita ventilantur ... (Leiden, 1671).

86 antro Trophonii: the Cave of Trophonius was a famous oracle of ancient Greece, albeit terrifying to consult. The Dutch reads: dat vuyle en wonderlijcke hol (that filthy and curious cave).

87 Deipnosophistarum: from the Deipnosophistae, a Greek work of Athenaeus of Naucratis (fl. late 2 nd century and early 3 rd century). The term describes people who excel in the refined conversation of Greek symposia, and is often used satirically, as here. The Dutch reads: Tafel-broers (literally 'table brothers').

88 Maresius, Tractatus brevis (see above, n. 74), p. 18. 
Particularly tempting is the connection to the discussions Graevius mentions over the latest books (which, as a side note, is probably what Voetius had in mind when he reportedly characterized the Utrecht meetings as a "scholars' daily"). Among all the works that appeared during the decade or so when the 'college' was actively meeting, two arguably stand out most: the Philosophia Scripturae Sacrae interpres (1666) commonly attributed to the Amsterdam physician Lodewijk Meyer (1629-81), and the Tractatus theologico-politicus (1670) of his friend the philosopher Benedict de Spinoza (1632-77). It is therefore only natural to suppose that both were read and debated in the context of the 'college,' all the more so due to the obvious threat these two expressions of a 'radical' Cartesianism represented to the Utrecht network. ${ }^{89}$ More than that, in Wolzogen, De Bruyn, and Van Velthuysen the 'savants' were quite well represented among the Philosophia's first public detractors, ${ }^{90}$ and one wonders whether their ideas, or perhaps even portions of their texts, were discussed at the meetings of the 'college.' A similar case can be made for Spinoza's anonymously published treatise. As has been demonstrated, shortly after the appearance of this work, the Utrecht Cartesians launched a veritable campaign against the Tractatus, which included recruitment efforts directed toward the celebrated Groningen orientalist Jacobus Alting (1618-79), as well as his former student, the Cologne minister Johannes Melchioris (1646-1689). The immediate flurry of anti-Spinoza activity in Utrecht, and its coordinated appearance, are in fact suggestive of collective discussions over the Tractatus theologico-politicus held in $1670 .{ }^{91}$ So, too, one wonders whether the massive, chapter-by-chapter refutation (Adversus anonymum Theologo-politicum liber singularis $^{92}$ ) that Van Mansveld wrote in the final year of his short life was not just a team effort in that fellow 'savants' Graevius and Wolzogen brought it to press posthumously, ${ }^{93}$ but also because it owed something to the meetings of the 'college' as Maresius describes them in the Tractatus brevis.

89 This has also been suggested by Eric Jorink, 'OOutside God, There is Nothing"' (see above, n. 13), p. 96, who also lists Adriaan Koerbagh's Een bloemhof van allerley lieflijkheyd sonder verdriet (1668) as a third possible candidate.

9o For the early response to Meyer's Philosophia, see Bordoli, Ragione e Scrittura (see above, n. 13), pp. $232-383$.

91 See Albert Gootjes, 'The First Orchestrated Attack on Spinoza: Johannes Melchioris and the Cartesian Network in Utrecht,' Journal of the History of Ideas 79 (2018), 23-43.

92 Regnerus van Mansveld, Adversus anonymum Theologo-politicum liber singularis (Amsterdam, 1674).

93 See on this the letters of L. Wolzogen to J. G. Graevius (Amsterdam, 24 March and 27 April 1674), Copenhagen, KB, MS Thott $12674^{\circ}$ (folder "Lud. Wolzogen"); and Gootjes, 'First Orchestrated Attack' (see above, n. 91). 
The literary production of the 'college' was a delicate point, however, particularly when it came to pamphlets. When Maresius referred to the "Trophonian cave" of the Utrecht Cartesians, he did so to identify it as the place where-as he had it from hearsay - "the satires of the masked [author] Petrus ab Andlo, ${ }^{94}$ written against me in favour of Cartesianism and Socinianism at the time the Pacific Theologian ${ }^{95}$ was preparing to go to press, were forged." 96 The charge of pamphleteering appears in the anonymous Het Collegie der sçavanten and Rehabeams raedt as well, as both recount how the 'savants' were aided by the city magistrates in bringing their pamphlets (pasquillen) to press. ${ }^{97} \mathrm{Of}$ course this charge is denied from the side of the 'college.' The pamphlet Bileams raedt, whose title reflects the contention that the preceding Voetian tract contains not the wise counsel given to King Rehoboam (cf. 1 Kings 12) but the treacherous advice of Balaam that seduced the Israelites to evil (cf. Numbers 31:16), counters that the pamphleteer is in the dark on this point, and furthermore insists: "One of the members has declared to me on this occasion, as they would all be ready solemnly to declare, that they have never put their hand or pen to this in their meetings, or have deliberated doing so."98 So too Graevius, following his description of the 'college' as a scholarly society, writes that the charge of pamphlet-making is false: "No pamphlet was ever written by this Collegium doctorum."99

While on the face of it the evidence over the pamphleteering charge presents us with a deadlock, consideration of the way the opportunistic Graevius writes as he finds himself in this tight situation appears to offer a way out. One gets the impression throughout that he has chosen his words most carefully when writing to Heinsius for support at the dawn of the new stadholder

94 That is: the pseudonymous pamphlets signed 'Petrus ab Andlo': Specimen confutationis dissertationis quam Samuel Maresius edidit De abusu philosophiae Cartesianae (Leiden, 1670); Animadversiones ad Vindicias dissertationis quam Samuel Maresius edidit De abusu philosophiae Cartesianae (Leiden, 1671); and Specimina bombomachiae Samuel Maresii se defendentis Clypeo orthodoxiae ceu Vindiciae vindiciarum dissertationis De abusu Cartesianiae (Leiden, 1672).

95 That is: Wittich, alluding to his Theologia pacifica (1671).

96 Maresius, Tractatus brevis (see above, n. 74), p. 18: "Quin fando accepi personati Petri ab Andlo, satyras mihi oppositas in gratiam Cartesianismi \& Socinianismi, dum se parabat ad justum praelium Theologus Pacificus, in illo antro Trophonii Ultrajectinorum Deipnosophistarum, cusas fuisse, unoquoque eorum suam symbolam eo conferente." Het Collegie (see above, n. 3), p. Biv; and Rehabeams raedt (see above, n. 7), p. 4. This is the only time the "Collegie De Sçavanten" (sic) is mentioned in the latter pamphlet.

98 Bileams raedt, (see above, n. 7), p. 7: “... ymant der leden heeft my verklaert by dese occasie, gelijck zy oock alle souden heylighlijck willen verklaren, noyt in hare byeenkomsten handt of pen daer toe geleent, of overlegh gemaeckt te hebben van sulcx te doen...." Letter of J. G. Graevius to N. Heinsius (Utrecht, 29 April 167[4]) (see above, n. 12). 
period. An example is the way he dissociates himself from the charge of Cartesianism: "I have constantly kept myself aloof from cultivating the teaching of Cartesian instruction, so far, in fact, that I do not even own any of his books, nor have I read them through."100 This assertion, and its more forceful version expressed to Constantijn Huygens the Elder (1596-1687) the following day, ${ }^{101}$ certainly seems exaggerated in light of Graevius's reputation as one of Utrecht's 'Cartesian professors.' Nevertheless, if this statement is read literally and under the assumption that Graevius formulated this passage very carefully, it may not, after all, be that far from the truth. For it is quite possible that his knowledge of Descartes's philosophy was largely secondhand, and his university appointment to lecture on history, rhetoric, and politics (rather than philosophy or theology) would have made it easy to steer clear of the more problematic elements of Cartesian epistemology, metaphysics, and physics. Moreover, in spite of his indubitable position within the Cartesian, republican camp, Graevius's actual commitments are difficult to pin down, in spite of the myriad surviving letters, since he rarely expressed himself on the substance of debate. So, too, the entire letter to Heinsius, written in the hope of saving his career in Utrecht, leaves one with the impression that it was cast in most careful terms to tell formal truths while skirting falsehood—witness his admission, on the one hand, that the 'college' once spent a winter poring over Descartes's replies to his sceptics in the Meditations, while insisting, on the other, that more poignant criticism was offered in their company than anywhere else. ${ }^{102}$

100 Letter of J. G. Graevius to N. Heinsius (Utrecht, 29 April 167[4]) (see above, n. 12).

101 Letter of J. G. Graevius to C. Huygens (Utrecht, 30 April 1674), Leiden, UB, BPL, cat. nr. 2212 (the minute is found in Copenhagen, KB, Thott $12684^{\circ}$ (folder "II. Breve fra Graevius uden Paaskrift til hvem"): "Multorum hominum minime levium sermonibus ad me perfertur, fuisse qui malignos de me disseminarint rumores, invidiosumque me facere apud Serenissimum Principem Arausionensem studuerint, criminantes me Cartesianae familiae alumnum esse ac sectatorem, nec bene de Principali gubernatione sentire. Nihil potuit dici falsius. Cartesii doctrinam tantum abest ut imbiberim, ut ne libros eius unquam evolverim perlegerimque. Non hoc mihi laudi duco: sed meorum studiorum rationes sunt alienissimae ab hoc scriptorum genere, nec tulerunt unquam ut iis pertractandis invigilare potuerim. His accedit quod a teneris annis innutritus sim praeceptis antiquorum dicendi sapiendique magistrorum, illorumque lectione capiar unice, quod non ignorant qui me publice privatimque in hac Academia \& in aliis gymnasiis audiverunt Aristotelem unice praedicantem, \& eius libros Rhetoricam imprimis, Ethicam \& Politicam iis commendantem non solum, sed \& ex illis multa de superiore loco explicantem. Nihil unquam docui, nihil scripsi, quod ullius animum, cuiuscunque ille sit ordinis \& loci \& sectae posset offendere, nec unquam de Serenissimo Principe ac eius gubernatione sinisterius existimavi. Hanc calumniam difflabit oratio, quam de laudibus Magni Principis scripsi, quae nunc typis mandatur."

102 Letter of J. G. Graevius to N. Heinsius, Utrecht, 29 April 167[4] (see above, n. 12): "Unius hyemis horae nonnullae subsecivae datae sunt examinandis argumentis, quae Cartesius 
Therefore, it may indeed be true that the 'college,' understood most literally in terms of its meetings, did not produce any of the anti-Voetian pamphlets in circulation. But there is little doubt that it was close to the fire. Graevius, at any rate, seems to have known more than he was willing to divulge. Thus, after denying that the Collegie ever made pamphlets in a letter to Heinsius, Graevius curiously adds that such pamphlets would have been printed even had there been no Collegie, and he remarks in closing: "At all events, I can plainly affirm in a sworn statement that nothing was mandated by writ from this college."103 The very next day Graevius sent Heinsius another letter, as his position was rapidly worsening because of those who spoke ill of him before the Prince of Orange. These detractors included Maresius's son Henri (fl. 1652-96), since "several years ago a number of pamphlets on Cartesian philosophy bearing the name Petrus ab Andlo were published against his father, which he believed to have come from that company I discussed with you yesterday."104 In this second letter Graevius again insists he is willing to swear that the booklets were published "without the knowledge of that college," but here, too, one cannot escape the impression that he actually knows more: "We might be able to guess at the author, but it is certain that he did not clearly stand with that company."105

Given the vested interest of both the Voetian polemicist and the desperate Graevius in their respective versions of the Utrecht 'college,' neither the precise involvement of this society in the production of pamphlets nor the identity of Petrus ab Andlo can be definitively determined as long as new evidence remains wanting. ${ }^{106}$ Nevertheless, there is no doubt that in the eyes of the Voetians, the meetings held by the 'college of savants' during the decade

in Meditationibus suis Scepticis opposuit. Pleraque a plerisque gravius sunt impugnata, quam ab ullo adversario."

103 Letter of J. G. Graevius to N. Heinsius (Utrecht, 29 April 167[4]) (see above, n. 12): "Saltem a collegio hoc nullum fuisse mandatum litteris possum juratus conceptis verbis affirmare liquido."

104 Letter of J. G. Graevius to N. Heinsius (Utrecht, 30 April 1674) (see above, n. 12).

105 Letter of J. G. Graevius to N. Heinsius (Utrecht, 30 April 1674) (see above, n. 12): "Possum ego quovis sacramento contendere inscio plane illo Collegio hos libros publicatos esse. Auctorem forte conjectura nos posse assequi, sed certum non constare liquido illi coetui."

106 Wim Klever was correct to draw attention to the scant evidence for the almost universally accepted identification of 'Petrus ab Andlo' as the Utrecht 'savant' Regnerus van Mansveld; see his 'Information on Spinoza and Some of his Acquaintances,' Studia spinozana 8 (1992), 297-309, there 305, n. 14. The attribution is supported only by a suggestion - and nothing more-Pierre Bayle once made in his Dictionnaire historique et critique, 1st ed. (Rotterdam, 1697), s.v. "Andlo (Petrus ab)," 1:259, n. B. At the same time, the reading of 'Andlo' as a cryptogram for 'Mansveld,' composed of the Greek root and(from the noun aner, meaning 'man') and the Dutch lo ('open clearing' $\approx$ 'field'), is quite tempting; see Bernard Glasius, Godgeleerd Nederland: Biographisch woordenboek van Nederlandsche godgeleerden, 3 vols. ('s Hertogenbosch, 1852-6), 2: 432, n. 1. 
or so of its existence were not as innocent as Graevius depicted them. On 2 May 1670 the Utrecht Dutch Reformed consistory took note of "the teaching of a certain college,"107 deciding a week later to speak to those "involved in certain disturbances during or over the teaching of a certain college."108 While this matter died a quiet death in the consistory acts, ${ }^{109}$ the prevalent suspicions concerning the kind of ideas the 'savants' were exchanging (in draft form or otherwise) at their meetings, and the polemical pamphlets they were thought to be producing, make it entirely possible that this represents a final piece of evidence for the Utrecht 'college.'110

\section{Conclusion}

The 'college of savants' is thus indeed an expedient collective term designating the circle of Cartesians that had gathered around Van Velthuysen and De Bruyn in Utrecht during the early 166os, and may be used as such. Nevertheless, of equal or even greater significance is their formation not long thereafter of a scholarly society, around the same time when the Royal Society, the Académie royale, and the Accademia del Cimento were being established respectively in England, France, and Tuscany. That this development has long been overlooked is due not only to the paucity of extant evidence for the abortive Utrecht enterprise but also to its underlying, highly charged polemical circumstances, leading to exaggerated accusations on the one hand, and half-truths passing over less convenient details on the other. Yet when the evidence is carefully sifted, it would seem that the Utrecht 'Cartesian professors,' along with several of the city's physicians and students from the university, and in the occasional presence of better- or lesser-known guests, met on a weekly basis from the mid-166os to sometime before the spring of 1674 to read canonical philosophical and political texts together under the guidance of an authority, to witness

\footnotetext{
107 Acts of the Utrecht Dutch Reformed consistory, Utrecht, HUA (see above, n. 49), inv. nr. 9 (2 May 1670): "Ad notam nopende het leeren van zeker Collegie in dese Stadt."

108 Acts of the Utrecht Dutch Reformed consistory, Utrecht, HUA (see above, n. 49), inv. nr. 9 (9 May 1670): “De Broederen van resp. Quartieren zullen aanspreken de personen van welke eenige ongeregeltheden waren voorgekomen op of omtrent de leering van zeker Collegie."

109 The final mention is in the acts of the Utrecht Dutch Reformed consistory, in Utrecht, HUA (see above. n. 49), inv. nr. 9 (23 May 1670): "Het aanspreken van het Collegie daar eenige ongeregeltheden in het leeven waren voorgevallen blyft ad nota."

110 The term collegie was used for a wide range of bodies, from less formal groups to officially instituted government entities. The very indefiniteness (cf. zeker, 'a certain') of the first passage above makes it tempting to understand it as a reference to the Utrecht collegie der sçavanten.
} 
medical experiments performed by specialists, to inform each other of the latest books and to discuss them, and to share some of their ideas in nascent or draft form. Moreover, despite Graevius's protestations, it seems reasonable to suppose that the 'savants' produced, or helped to produce, anti-Voetian pamphlets, whose contents were at least to some degree inspired by the discussions held during their weekly meetings.

That the Utrecht 'college' failed to last and has largely fallen into oblivion is not entirely coincidental. By virtue of the enormous correspondence by which he gained the latest news, Graevius might be seen as a kind of intelligencer like Henry Oldenburg (1619-77). Yet as for the rest, the reports attributing some kind of formal structure to the 'college' conflict with each other, and their polemical nature makes it difficult to give one preference over the other. The Royal Society and the Académie royale, in contrast, each possessed not only a fixed organizational structure but also benefited from royal patronage promising them longevity. With the financial backing and interest of the Medici family, the Tuscan Accademia del Cimento would have enjoyed a longer life than the decade of its actual existence, had it not lost several of its key members within a short span. ${ }^{111}$ Moreover, these societies all had an overriding experimental-Baconian or otherwise - program that required suitable tools and materials. Therefore, for the Utrecht 'college,' a member initiative without a formal institution or physical location, it would have been even easier simply to peter out and die - what appears to have happened after Wolzogen left for Amsterdam late in 1670 , followed half a year later by the unexpected death of Van Mansveld.

But another reason for the demise of the 'college' was doubtless its somewhat ad hoc character within the theological and political climate specific to Utrecht and absent elsewhere. It was there that the 'conservative' camp of the public church, with its broad understanding of societal reform, continued to make its presence known, a fact that several 'savants' - who appear for all intents and purposes to have remained orthodox, still holding to such major doctrines as the Trinity, Christ's twofold nature, and even predestination ${ }^{112}$ experienced firsthand following upon their books and disputations. On the one hand, the local circumstances under which the 'college' grew makes it

111 For an account of the demise of the Accademia, see William E. Knowles Middleton, The Experimenters: A Study of the Accademia del Cimento (Baltimore, 1971), pp. 309-29.

112 For a fine treatment of the Remonstrant theologian Philippus van Limborch's (1633-1712) accusation that Burman was a Spinozist, see Simonutti, "Tra Cartesianesimo e Spinozismo" (see above, n. 64). Interestingly, this same rumor is noted in a student jotter from the later 1670s; see Steenbakkers, Touber, and Van de Ven, 'A Clandestine Notebook" (see above, n. 7), p. 286 (entry nr. 93): "burman omnem suam doctrinam traxit ex spinosa." 
unfair simply to dismiss it as a "weekly chat among likeminded friends." 113 For the meetings held in a closed circle provided the members with the very platform they needed in order to discuss and weigh the latest philosophical and scientific advances, as well as religious conceptions, away from the pervasive interference of the Voetians. Most illustrative in this regard may be the 'savant' response to a work as heretical as Spinoza's Tractatus theologicopoliticus. While the Voetian consistory immediately sought to have the book proscribed by the authorities for its content, ${ }^{114}$ the 'savants,' who fully agreed that the Tractatus was a blasphemous book, ${ }^{115}$ were also highly intrigued by Spinoza's ideas, which they quite probably discussed at their meetings, obviously admiring his brilliant mind and consciously working on a refutation they judged to be worthy of him. ${ }^{116}$ On the other hand, the reactionary character of the 'college' as a response to local political and ecclesiastical circumstances also meant its life could be cut short, as it indeed was. Even apart from the question of patronage and dwindling numbers, the Utrecht 'college of savants' above all lacked a positive ideal around which it might have rallied when, late in 1673 or early in 1674 , the need for breathing space was no longer felt as poignantly as it had been a decade earlier at its inception.

113 So De Vleeschauwer, "Alarm-pamflet" (see above, n. 11), 571, n. 66: "wekelijksch onderonsje van gelijkdenkende vrienden...."

114 Acts of the Utrecht Dutch Reformed consistory, in Utrecht, HUA (see above, n. 49), inv. nr. 9 (8 April 1670). This is, incidentally, the very first mention of the Tractatus anywhere after its publication.

115 E.g., letters of J. G. Graevius to G. W. Leibniz (22 April 1671): "liber pestilentissimus" and (27 April 1671): "sacri illius et horribilis libri", in: Gottfried Wilhelm Leibniz: Sämtliche Schriften und Briefe, ed. Deutsche Akademie der Wissenschaften (Berlin: Akademie Verlag, 1923-), 1/1:141-5 (nrs. 82 and 83).

116 See my 'First Orchestrated Attack' (see above, n. 91). 